Wacana Vol. 18 No. 2 (2017): 422-454

\title{
Bangsawan prampoewan \\ Enlightened Peranakan Chinese women from early twentieth century Java
}

\author{
DIDI KWARTANADA
}

\begin{abstract}
The end of the nineteenth century witnessed paradox among the Chinese in colonial Java. On one hand, they were prospering economically, but were nonetheless held in contempt by the Dutch, encountered legal discrimination and faced challenges if they wanted to educate their children in European schools. Their marginal position motivated them do their utmost to become "civilized subjects", on a par with Europeans, but they were also inspired to reinvent their Chinese identity. This contribution will highlight role played by "enlightened" Chinese, the kaoem moeda bangsa Tjina. Central to this movement were the Chinese girls known to the public as bangsawan prampoewan (the noblewomen), who wrote letters the newspaper and creating a gendered public sphere. They also performed western classical music in public. Considering the inspirational impact of bangsawan prampoewan's enlightening achievements on non-Chinese women, it is appropriate to include them into the narrative of the history of the nation's women's movements.
\end{abstract}

KEYWORDS

Chinese; women; modernity; progress; newspapers; Semarang; Surabaya; western classical music; Kartini.

DIDI KWARTANADA studies history of the ethnic Chinese in Indonesia, especially Java. He is currently the Director of the Nation Building Foundation (NABIL) in Jakarta and is preparing a book on the history of Chinese identity cards in Indonesia. His publications include The encyclopedia of Indonesia in the Pacific War (Leiden: Brill, 2009) as co-editor and contributor, and the most recent work Tionghoa dalam keindonesiaan; Peran dan kontribusi bagi pembangunan bangsa (3 vols; Jakarta: Yayasan Nabil, 2016) as managing editor cum contributor. Didi Kwartanada can be contacted at: kwartanada@yahoo.com.

(C) 2017 Faculty of Humanities, Universitas Indonesia

DIDI KWARTANADA | DOI: 10.17510/wacana.v18i2.591. 


\section{INTRODUCTION $^{1}$}

[...] since in this age of progress, not only did males compete for the highest levels of achievement, but also, as you gentlemen and ladies already know, many females competed in seeking knowledge in the pages of the newspapers; it can be said that all the weekly newspapers which strove to enlighten the Chinese people had female editors, to the point of causing resentment among the conservatives ( $\mathrm{si}$ kaoem toewa). Almost every day they grumbled, objecting to one thing or another. (Tjoa Phik Nio 1906: 2.)

The letter cited above was written in 1906 by Tjoa Phik Nio, a Peranakan lady from a small city in East Java. It might not be well written and uses irritatingly long sentences, but this was the style of her contemporaries. Pertinently, the message she delivered was an extraordinary one in the early twentieth century. Her letter signified a woman's modernity and her discovery of the brave new world offered by the newspapers. Phik Nio proudly states that she was one of the kaoem moeda, who were striving for progress, and despised the kaoem toewa, who could not hold back the progress of women.

At the turn of the twentieth century, the main inspiration of educated people in Java was the modernity introduced by the westerners. It was exemplified by the popular Dutch words: vooruitgang (progress), opheffing (elevation), ontwikkeling (development), and opvoeding (education), all are words signifying progress (Shiraishi 1990: 27). The Javanese who were inspired by European learning referred to it using the hybrid term kawruh Eropah (European knowledge) (Ricklefs 2007: 136). Generally speaking, western learning was known in Malay as adjaran kemadjoean Eropa (Dutch: de leer van de Westersche beschaving), "the doctrine of western civilization" ("Lezingnja R.M. Soeleiman" 1909).

Western knowledge also had its admirers among the Chinese. A Peranakan Chinese from Makassar (South Celebes) sent a personal letter to the GovernorGeneral in Buitenzorg, exclaiming " [...] the science of the Dutch nation, which rules us here in the Indies, is the epitome of learning, as is used by various nations around the world " (Nationaal Archief/NA, Ministerie van Koloniën/ MvK, 2.10.36.04 \#418). Anyone educated in western manner would do their best to master de Westersche beschaving, because winning the accolade of a beschaafd (civilized) person was one of their ultimate goals in life. As Takashi Shiraishi has stressed, mastery of Dutch was an indispensable means for an Asian to be considered as "civilized":

The key was their knowledge of Dutch and their access to the Dutch world in the Indies, for the Dutch exemplified modernity and the Dutch language was the key to open the modern world and age (Shiraishi 1990: 30).

1 I would like to thank especially to Professor Anthony Reid and Dr Mark Ravinder Frost, who helped shaping my ideas. I am also grateful to Peter Post, Oei Him Hwie, Tan Soon Cheng, Dr Susi Moeimam, and Evelyne Yudiarti. Last but not least, to the anonymous reviewer for the constructive remarks and Ibu Rosemary Robson for polishing my English. 
The struggle to be "civilized", and hence on a par with westerners, was a common aspiration in Asia at the turn of the twentieth century. In Siam, in its goal to be accepted as an equal by the modern nations, the government sponsored a project to modernize the country and its subjects. Siwilai, the Thai word for "civilized", ranked among the most important popular agenda items in early-twentieth-century Siam (Winichakul 2000: 528-49). As an outward and visible sign, sartorial modernity played an important role in a project for the enhancement of status. A recent study of Siam reveals that "the dress and clothing practices became central to the Thai monarchy's agenda of projecting itself as distinctly 'modern' and therefore 'equal' to the West" (Roces and Edwards 2007: 9). The same could be said of Japan, where western dress was the badge of civilized status (Hirano 1993).

The Chinese in Java were even more exposed to this pressure for civilized status than the Javanese. In the late-nineteenth century, bowing to the criticism of Dutch politicians and journalists who saw the tragic poverty suffered the ordinary Javanese, the Dutch government adopted an "Ethical Policy" to improve their lives. The same movement tended to blame Chinese bloedzuigers der Javanen ("the bloodsuckers of the Javanese") (Lohanda 2002: 22-30) for causing the misery of the latter. Therefore, the late-nineteenth century was not a good time for the Chinese. The Dutch placed severe restrictions on Chinese children attending European schools; they had to live in their ghettos and apply for travel passes. The long-time source of colonial government income, revenue farming, was abolished and the system latered into a government monopoly. After a struggle, the rising Japanese, fellow Asians, acquired European legal status (1899), leaving the Chinese to feel they were secondclass "Foreign Orientals". What could they do to achieve "civilized" status?

\section{INTRODUCING “THE ENLIGHTENED” CHINESE}

This contribution is an effort to elucidate a group of Peranakan Chinese, who described themselves in Malay as kaoem moeda bangsa Tjina (literally: the young group of the Chinese nation) (Rivai 1906-1907; Kwee Tek Hoay 2001: $414)^{2}$ or in Dutch as Jong Chinezen (Young Chinese) ("Chineezen" 1917). In English researchers give them various names: Lea Williams (in Kwee Tek Hoay 1969: 13) translates the phrase as "the progressives", ${ }^{3}$ while other sources use "reformers". Although all these English translations are appropriate, I have rendered this into English as "Enlightened Chinese", because their commitment to modern education and progress contributed to the making of modernity in Java at the turn of twentieth century (Adam 1985: 3-14).

"Young China" or Jong Chinezen implies a greater connection with China, perhaps inspired by other "young" movements, as among them the Young Turks in Turkey. The term is problematic since it sounds Sino-centric,

\footnotetext{
2 A well-known Indonesian author invented his own term "Angkatan Muda Cina di Hindia" (Toer 2003: 166).

3 On the same page, note 25 Williams explains "the term means youth faction, but progressives renders the sense more adequately".
} 
whereas besides wanting to resinify themselves as Chinese, the "enlightened" Chinese, also sought to be "civilized" subjects, emulating the westerners. Therefore, "Young China" is too narrow to translate kaoem moeda bangsa Tjina. "Reformers" is also less than satisfactory, since the kaoem moeda not only reformed practices, but also embraced modern institutions, ranging from western-style schools to sports and debating clubs (Kwartanada 2013: 27-44). Finally, "progressives" has political connotations, and in certain places refers specifically to the left wing, whereas, in the period I am discussing, the kaoem moeda strove more towards modernity. The image of light was also widely used in contemporary sources. Educated Chinese often referred to their fellows trapped in conservatism as those who lived in darkness (Malay: djaman kegelapan). It was the role of the kaoem moeda to enlighten their fellows. Li Po, the newspaper which supported the kaoem moeda movement, was called Palita Tjina (the Chinese Oil Lamp). The dichotomy of light and darkness was a common metaphor in the early-twentieth century public sphere (Anderson 1979: 219248). Contemporary observers also found the spirit of "enlightenment" among the kaoem moeda. Observing the first modern Chinese school, the Tiong Hoa Hwee Koan (THHK), Henri Borel, the Dutch translator of Chinese, saw that it ranked an enlightened spirit above nationalism in its agenda: "that spirit strove first and foremost for enlightenment and the advancement for the Chinese, and [only] was the second place was strongly Chinese-nationalistic" (Borel cited in Govaars-Tjia 2005: 62, italic is mine).

While it is true that intellectuals are often in the vanguard of reform or nationalist movements (Hutchinson 2001: 154-157), I hesitate to call the kaoem moeda a group of "intellectuals", because they were not necessarily scholars. I prefer to use the term "enlightened" Chinese. An ordinary man like Tjoa Tjeng Jang from Soekaboemi, ${ }^{4}$ or a wealthy businessman like Oei Tiong Ham from Semarang, could be an influential kaoem moeda. They were not intellectual in the sense of being highly educated, but their actions did have an enormous impact on their fellow Peranakans.

Who were the kaoem moeda bangsa Tjina? Chinese were considered pariahs in colonial Java. Although they prospered economically, they faced discrimination in politics, law and education. Therefore, the kaoem moeda consisted of western-educated, or otherwise progressive men and women, primarily Peranakan (local-born ) but complemented by a few totok (the Chinaborn), who were dissatisfied with their position as second-class citizens in the new world of the twentieth century. They believed that embracing modernity was their only path towards achieving a "civilized" status in colonial Indonesia. In the eyes of the Dutch, a perfect Chinese was "a very civilized, Dutch-speaking Christian Chinese person" (een zeer beschaafde, nederlandsch sprekende christen-chinees) ("Wat de Chinees Vertelt" 1-4-1909). However, the kaoem moeda wanted to be on a par with the Europeans without joining them as Christian converts; they wanted to be equal in modernity but separate as

4 The influential magazine Bintang Hindia claimed that Tjoa was the first Chinese in the Indies to cut off his pigtail ("Baba Tjoa Tjeng Yang" 1903: 247). 
Chinese. This accords with Dr Abdul Rivai's description of the kaoem moeda as those who embraced modernity without losing sight of their background (Poeze 1989: 94-95).

As early as 1901, the enlightened Peranakan women in Java, apparently more advanced than their sisters in Singapore and Malaya, discarded their traditional reticence and enthusiastically sent letters in romanized Malay to various newspapers. ${ }^{5}$ This new generation of enlightened young Peranakan women found a new medium through which to express their thoughts and ideas of "modern" yet "authentic" Chinese women, gender equality and progress. Dr Abdul Rivai, editor-in-chief of the influential magazine Bintang Hindia, coined the term Bangsawan Pikiran [the Nobility of Intellect] for the kaoem moeda (Adam 1995: 103). However, to honour the enlightened ladies, I shall call them - on the basis of a 1907 article - "the noble women" (bangsawan prampoewan) ("Concert Mej. Oei Tiong Ham" 1907).

This essay will explore the origins and activities of the bangsawan prampoewan. Where did they acquire their modern education and literacy in the Roman alphabet? Who were they? What did they do to inspire other women? Who supported them in their aspirations? Above all, what did they discuss in the gendered public sphere created in the early-twentieth century?

\section{Modern education for Peranakan girls}

The best opportunity to obtain western knowledge in colonial Indonesia was by attending the European Elementary School (Europeesche Lager School/ ELS) and Dutch High School (Hogere Burgerschool/HBS). However, since the nineteenth century the Dutch had tried to deter the Chinese from attending these schools, whose principal role was to educate the children of Europeans (Groeneboer 1998: 98-103). Therefore, only limited opportunities to obtain a modern education were open to Peranakan boys in the late-nineteenth century, and the girls had even fewer chances.

The main barrier to the girls receiving education was the traditional Chinese custom of keeping a girl inside the house (Malay: dipingit) when she reached the age of twelve until her wedding day (End 2006: 199). ${ }^{6}$ However, thanks to the open-mindedness of a handful of enlightened fathers, a number of young ladies managed to acquire western learning and the Roman alphabet through various media. The number of female students in various government and missionary schools is shown in Table 1.

\footnotetext{
$5 \quad$ I have found letters published in the kaoem moeda newspapers, such as Li Po (Sukabumi) and Ik Po (Surakarta), and very possibly there are more letters in other enlightened papers.

6 The American missionaries of 1820s Java had reported such custom, see Lake (2004: 37). However, dipingit was not an exclusively Chinese custom; the Javanese also practised a similar custom. Most famous is the story of Raden Ajeng Kartini (1879-1904), an enlightened Javanese noblewoman in the late-nineteenth century, whom we shall discuss at the end.
} 


\begin{tabular}{|c|c|c|c|}
\hline \multirow{2}{*}{ Year } & \multirow{2}{*}{$\begin{array}{c}\text { Number of Chinese } \\
\text { Students }\end{array}$} & \multicolumn{2}{|c|}{ Female component } \\
\cline { 3 - 4 } & 1,006 & Number & Percentage \\
\hline 1882 & 1,329 & 2 & 0.19 \\
\hline 1887 & 1,111 & 5 & 0.37 \\
\hline 1888 & 1,038 & 13 & 0.45 \\
\hline 1892 & 995 & 18 & 1.25 \\
\hline 1893 & 1,200 & 54 & 1.80 \\
\hline 1897 & 2,043 & 123 & 4.50 \\
\hline 1900 & & & 6.02 \\
\hline
\end{tabular}

Table 1. Number of Chinese students in various government and missionary schools in Java (1882-1900) (source: Algemeen vijfjarig verslag van het inlandsch onderwijs in Nederlandsch Indië 1880-1907: various editions from 1873-1904; ELS data are taken from Koloniaal Verslag 1878-1898: Hoofdstuk K).

The figures show a slow growth in the number of peranakan girls in Western education between 1882 and 1900. The absolute number looks small, but in percentage terms we see marked increase. Furthermore, the figures are far from complete, since other girls who studied in various non-government and non-missionary schools and some also studied at home with private European tutors/governesses, a figure not covered in Table 1.

The increasing number of girls also reflects the changing perception of Peranakan parents in Java about female education at the end of the nineteenth century. However, progress was still in its initial stages, because a proportion of the parents were unhappy about their daughters mixing with boys ("Tiong Hoa Lie Hak Hauw"; Govaars-Tjia 2005: 56). Aware of the problem, three forms of action were taken by school boards. Firstly, boys and girls were taught separately; the latter were placed in a special classroom. This was a common pattern in the early years of THHK schools, for instance, those in Batavia and Malang (Nio Joe Lan 1940: 14, 25; 35 Jarig Jubileum 1940: Chinese section: 1). A second strategy was for boys and girls to study together in the same classroom, but seated separately according to gender ("Tiong Hoa Lie Hak Hauw"). Finally, special schools for girls (roemah sekola boeat anak-anak prampoewan) were established.

It is interesting that the first special school for girls was founded not in Java, but in Makassar (South Celebes) in 1899 (Govaars-Tjia 2005: 217 note 56). Unfortunately, we know almost nothing about this school. In June of the same year, a group of Chinese reformers in Singapore, among them Dr Lim Boon Keng and Song Ong Siang, established the Singapore Chinese Girls' School, the first modern school of its kind. The subjects offered were Romanized Malay, Chinese and English, arithmetic, geography and needlework, and its first school teacher was a British lady. Khoo Seok Wan, another well-known Straits Chinese reformer who was greatly concerned about female education, donated generously to the new school (Song Ong Siang 1967: 305). Interestingly, when 
the school in Makassar was looking for teachers, it turned to Singapore for help. In May 1901, Khoo Seok Wan was entrusted with the task of finding a suitable lady teacher for the school. It turned out that finding a proper teacher was not an easy task. He had to advertise for more than two months in a Singapore Chinese newspaper, Thien Nan Jit Pao, before he was able to find one in July 1901 (Chen Mong Hock 1967: 125). This Makassar-Singapore connection resembles the case of the THHK school in Batavia and Lim Boon Keng's network at about the same time (Kwartanada 2013: 27-44). Again, Singapore played an important role as the centre of knowledge in the region.

The first modern Chinese school, Batavia's Tiong Hoa Hwee Koan, accepted girls as its students from its establishment in 1901. The girls were called nona-nona schola di Tiong Hoa Hwe Koan (THHK student girls) ("Liauw Tong Seng dan Liauw Koei Seng Kleermaker" 1907: appendix). The curriculum consisted of Romanized Malay, some Chinese script, arithmetic, geography, Chinese customs and other useful subjects. Two years later, a female European teacher was appointed to teach needlework skills such as sewing and knitting in the fourth grade and above (Nio Joe Lan 1940: 14, 25). As elsewhere, girls' education was seen as an indicator of the progress achieved in a society. The THHK Batavia was aware of this situation and on several occasions it sent female students to other schools and places to demonstrate the progress achieved by the girls. A newspaper report in December 1906 says that the THHK school in Batavia sent three members of the central board and two schoolgirls to a THHK school in nearby Serang. The two little girls amazed the audience when they delivered speeches (Hokkian: janswee), which were described by one of the audience as "very well done, resembling very clear, shining light" (amat bagoes laksana satoe pelita bertjahaja jang amat trangnja) (B. Tionghoa 1906: 1).

Another element signifying a modern education and identity in the THHK school was the cap (in Dutch: pet and Malay: pet kopia) bearing a motto in Chinese script Tiong Hoa Hak Tong (Mand: Zhonghua Xuetang, Chinese school). This headgear was adopted from the uniform of the most prestigious school, the HBS: a black cap with golden star in the middle, the source of great pride to those who wore it. In the early- twentieth century a Dutch lady wrote that the pet "became a sort of a new uniform, a piece of cloth, a sign of modernity, worn particularly daringly and elegantly by 'our boys', the students of the new Indies" (Mrázek 2002: 135). Interestingly, the THHK extended the use of the pet to its female students as another signifier of modernity (see Figure 1). ${ }^{7}$

7 In Meiji Japan, the Japanese schoolgirl "was far behind the boy in wearing a westernized uniform". They dressed in more traditional style uniforms until some private girls' schools took the initiative of adopting westernized ones in the Taisho period (1912-1926) (Hirano 1993: 127). 


\section{LIAUW TONG SENG dan LIAUW KOEI SENG KLEERMAKER \\ TANAH-L APANG GLODOK-BATAVIA.}

\begin{abstract}
Selamanja uda sedia roepa roeps pakean boewat nena sona Tiong Hoa seperti Badjoe Sioki \& Koen ketjil dan besar matjem matjem klear.

Dan ada sedia pet Kopis dari Trico dan flanel boeat nona nona schola dí Tiong Hoa Hwe Kwan.

Lagi ada sedia trico en flanel bakal bikin djas dan Tjelana Ollanda djoega trima kerdjaban boeat bikin, pake pakean, kerna kerdja'an di tanggoeng baek dengen onkost lebi moera dari laen onng.
\end{abstract}

1189

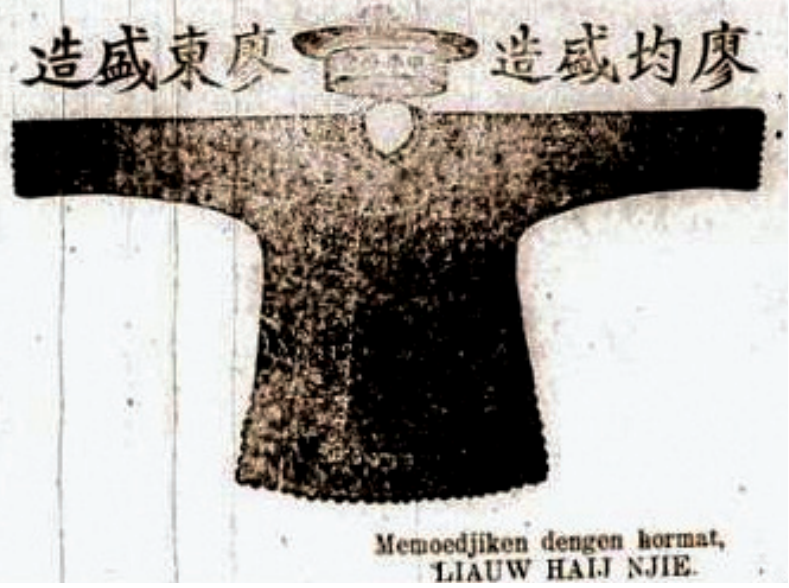

Figure 1. Hybrid uniform: Badjoe Sioki \& Koen, the Chinese dress for nona-nona schola di Tiong Hoa Hwe Koan, with a modern cap (pet kopia) (source: Perniagaan 16-11-1907: Lampiran).

Soon the new uniforms were in great demand among Peranakan families, as shown by the popular advertisements (Figures 1 and 2). However, "the most striking is the girls' uniform", wrote a newspaper ("De Chineesche School te Buitenzorg" 1912). The kaoem moeda invented a "modified" traditional dress, the so-called Badjoe Sioki and Koen (dress and petticoat). ${ }^{8}$ This set of clothes was regarded by some people as "the authentic clothes of the Chinese female" (L.S. 1909:1), similar to "that worn at the same period by ladies in China". This uniform gained popularity in Batavia thanks to the daughter of Lieutenant Lie Hin Liam, a prominent Chinese officer, who used this modified traditional dress ("De Chineesche School te Buitenzorg" 1912). The cap and dress style created a degree of assimilation between traditional and modern dress styles (Figure 2). However, the uniforms adopted varied from one place to another, depending on the decision of the school's board of governors. Photographs from THHK schools in various localities show a high degree of diversification between the "hybrid" and "modern" uniforms.

Such diversity, however, was not common among women in other parts of Asia. When the new Republic of China issued regulations on formal clothing in August 1912, the men could opt for either Chinese or European clothing, but the Chinese style was the only choice open to the women (Edwards 2007: 47 caption to Figure 3.1). A study of changing clothes styles in Japan during the 
Meiji Period shows that Japanese men were also quick to change their clothing style; but the women clung to the old ways. It is argued that the excessive westernization sponsored by the state sparked a feeling of nationalism and a number of people "wanted to preserve and revive their culture" to counteract the state's programme (Hirano 1993: 128).

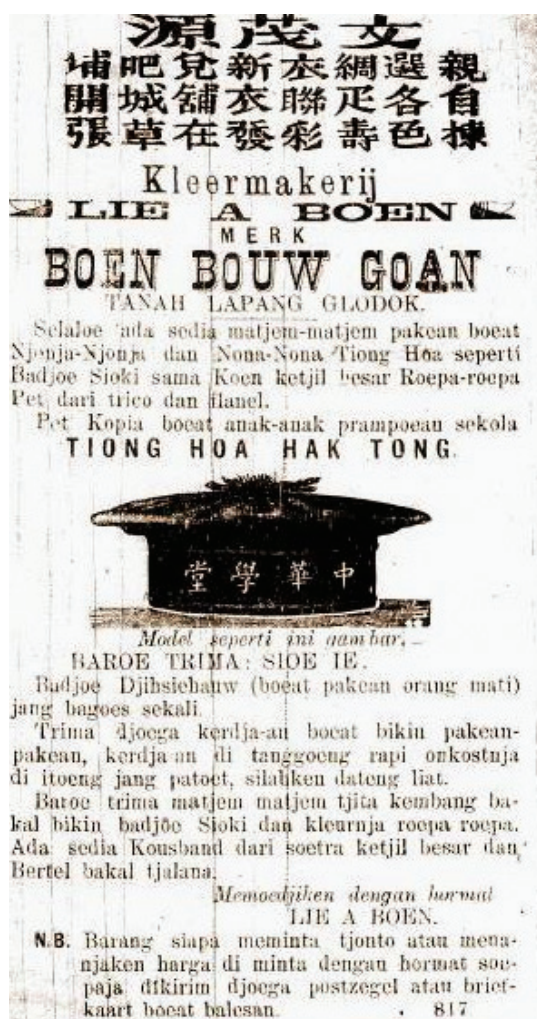

Figure 2. The cap (pet kopia) for Chinese schoolgirls at the Tiong Hoa Hwee Koan School. Text on the cap is Tiong Hoa Hak Tong (source: Perniagaan 20-4-1907: Lampiran).

Apparently it was the missionaries in West Java who pioneered the founding of special schools for Peranakan girls in Java. The first was opened in Bandung in 1902 and four years later another was established in Indramayu, although we know little about either (End 2006: 15). The opportunity for Peranakan girls to obtain the best possible modern education finally came on 1 July 1908, when the Dutch, anticipating the "subversive" impact of the Tiong Hoa Hwee Koan, finally opened the long-awaited Holland-Chineesch Schools (HCS/Dutch-Chinese School) in Batavia, Semarang and Surabaya (Govaars-Tjia 2005: 85). Like the THHK, the HCS was open to girls, but the two were very different in terms of subjects they offered.

Finally, "the first modern Chinese girls' school" (after Govaars-Tjia 2005: 56) was opened in Blandongan Street, Batavia in 1916. ${ }^{9}$ In Hokkien it was

9 This part is summarized from "Tiong Hoa Lie Hak Hauw" (Chung Hua Hui Archive 182, IISG Amsterdam). On the founding year, Nio Joe Lan (1939: 85) cited a year earlier. 
called the Tiong Hoa Li Hak Hauw or in Dutch: the Chineesche Meisjes School. Restricted by its limited budget, in its initial years this school offered only courses in Mandarin and Chinese script, taught by three female teachers. When the budget allowed, they planned to introduce all the following subjects: housekeeping, handicrafts, Dutch (Roman) alphabet and language, and culinary lessons, which would be taught by a Dutch female teacher. The curriculum stressed the teaching of domestic subjects, adducing the following arguments:

For the woman is the mother of the country. She takes heavy responsibility in running the household, takes care of the husband and educates the children. If a woman is not ultimately educated, and later has little knowledge, she will surely be unable to manage household financial affairs and educate the children properly. Therefore, if [we] want to develop a country, it is essential to improve the education for women. The progress and prowess of Germany and Japan and the wealth of England, the United States and France, are made possible because those countries are aware of the need to give education to women. (Govaars-Tjia 2005: 56.)

In 1916 the school attracted 27 pupils. Most were daughters of conservative parents who rejected co-educational classes. In several cases, when the daughters reached puberty, their parents removed them before they were able to finish their studies. Therefore, rather ironically Ming Govaars-Tjia claims that the Tiong Hoa Li Hak Hauw was "a breakthrough in education for girls" (Govaars-Tjia 2005: 56); ${ }^{10}$ a modern school, yet the outcome was conservative.

Sending their daughters to study abroad was another choice open to wealthy families. Apart from the Netherlands, China and Japan offered alternative choices. In 1905 Lieutenant Khoe A Fan, another enlightened Chinese officer, sent his three daughters to study in Japan. To demonstrate the quality of Japanese education, one of the daughters delivered a talk in Mandarin at the THHK School in Batavia, comparing education in Japan with that in the Dutch Indies. At the end she called for women to use Mandarin, "our own language". This was the first ever occasion on which a girl gave a speech at the THHK school and her impressive talk was received with loud cheers from the audience ("Wat de Chinees Vertelt" 9-9-1909: 4-5).

It is still unclear why the kaoem moeda showed less interest in female education in Chinese, since the first Chinese girls school, the Tiong Hoa Lie Hak Hauw, was only established at Batavia fifteen years after the founding of the THHK School. When Dr Lim Boon Keng, the founder of the Singapore Chinese Girl School (SCGS), visited Java on a fund-raising trip, he could only collect the small total sum of 500 guilders, donated by Lieutenants Lie Hin Liang and Lie Hin Liam, and Messrs. Tan Kong Djiam, Tan Oen Liong and Tan Sik Giok [Seck Geok] (The Hon. Secretary [Lim Boon Keng] 1907:

10 Unfortunately, we do not know much about this school. It was still in existence in 1940 and employed 10 teachers, which meant it had developed throughout the years (Govaars-Tjia 2005: 262). 
166). It is quite surprising that even the prominent kaoem moeda, for example, Lie Hin Liam and his brother, donated such a small amount. On the other hand, conservatism was still well entrenched. At the end of 1911, the press reported that the number of schoolgirls attending THHK schools was "still very small" ("De Chineesche School te Jogjakarta" 1912: 5). One reason was that the important role of providing modern education for Chinese girls had been poached upon by Dutch-Chinese schools, which modern Peranakan parents preferred to either the THHK or other private Chinese schools. They made good use of this opportunity, access to which had been hindered by almost insuperable hurdles in the nineteenth century.

\section{Tiong HWa Wi Sien Po: PIONEer of THE WOMEN'S PRESS}

The desire for progress among enlightened Peranakan ladies was finally satisfied with the publication of Tiong Hoa Wi Sien Po (hereinafter THWSP) in 1906. It adopted a name which means 'The Chinese Reformist Newspaper'. This was a newspaper aimed specifically at women and it published more contributions from them. Earlier enlightened newspapers, such as Li Po and Ik Po, had published letters and opinions from women, but they were scattered and appeared only irregularly. The THWSP was a weekly published in Buitenzorg by Kek Beng Tong (it literally means: the "Young-Chinese Party"), a group of enlightened Peranakan who supported the views of Kang Yu-wei and other reformers in China (Bliek 1910: 62; Salmon 1984: 154). Interestingly, when Kang visited Batavia in 1903, the Chinese ladies there also showed great interest in the Qing literati. Since some tetamoe-tetamoe prampooean (women guests) wanted to the opportunity to meet him, the THHK organized a gathering which it decided should be held in the THHK building, in the presence of THHK committee members (Nio Joe Lan 1940: 65). Although the interest of those women might have been piqued by curiosity, some of them must have been really interested in having a serious discussion with Kang.

The THWSP claimed to be the voice of the kaoem moeda. It consisted of two rubrics, one for male readers and the other for females ("Wat de Chinees Vertelt" 3-12-1908: 4). Its special section specifically designed for female readers was what distinguished this paper from other contemporary Peranakan newspapers. ${ }^{11}$ Claudine Salmon (1977: 160; also Zaini-Lajoubert 1994: 16) went as far as to baptize the THWSP "the pioneer of the woman's press in Indonesia". This claim is supported by the fact that the first Indonesian women's journal, Poetri Hindia, was published only in 1908 by the father of modern Indonesian journalism, Tirto Adhi Soerjo (Toer 2003: 7, 11). ${ }^{12}$ A prominent Dutch missionary commented on the THWSP:

11 It seems that the original copies of earlier years of the THWSP no longer exist. The National Library in Jakarta has only later issues of the Tiong Hoa Wi Sien Po; Orgaan boewat kaoem moeda bangsa Tiong Hoa (bagian laki2), twelfth year (1917)-fiteenth year (1920) (Santoso 1984: 179). Claudine Salmon (1984: 155) also lamented the absence of earlier issues.

12 Other source says it was published a year earlier (Douwes Dekker 1909: 264). 
A weekly which was edited by a Chinese woman, the Tiong Hoa Wi Sin Po (Buitenzorg), the organ of the Kek Beng Tong (Young-Chinese Party) [...] The tone of this paper, according to Koloniaal Weekblad, is always calm and dignified, which is attributed to the influence of its Chinese lady editors. (Bliek 1910: 62.)

This remark is very interesting, because it mentions that the paper also employed Chinese women as editors (Dutch: der Chineesche dames redactrices). Indeed, there was a Mrs Lim Titie Nio ("Wat de Chinees Vertelt" 3-12-1908: 4), who was perhaps the first woman in Indonesia to be an editor of mass media. According to a source, the newspaper was established by Tan Tjhan Hie, whose brother, Tan Ging Tiong, had published another newspaper with the same bent, Li Po since 1901 (Salmon 1977: 160). ${ }^{13}$ The motto of theTHWSP was: "a torch for men, an instructor for ladies, a whetstone for all those principles directed towards the refinement of mind and work, as well as the encouragement of devotion towards HM Queen of the Netherlands" (Bliek 1910: 62).

Among the topics covered, the THWSP published inspiring reports about enlightened Chinese women in various countries; insisting that they "were not second to men" (tidak kalah dengan laki-laki) (Oei Kok Nio 1906: 2). The Dutch press called the THWSP the "women's paper" (vrouwenblad) which struggles for "female emancipation" (vrouwen emancipatie) ("Vrouwenblad" 1912: 100-101).

\section{SOERAT PEMBATJA: LETTERS TO THE EDITOR}

Letters to the editors of the newspapers, articles and editorials written by overseas Chinese women have recently seen the light in academic studies. Judy Yung's study of Chung Si Yat Po (CSYP), one of "the most successful and long-lasting Chinese language newspapers of early twentieth century America" discovered "approximately 550 articles and 66 editorials about women (2 percent of the newspapers pages), 26 of which reflected the voices of Chinese women themselves appeared in CSYP" between 1900 and 1911. The issues discussed in CSYP were similar to issues raised in China: (1) the eradication of pernicious practices harmful to women, such as polygyny, arranged marriages and foot-binding; (2) education for women; (3) women's rights; (4) women's role in national salvation (Yung 2008: 260).

However, this essay will focus only on the soerat pembatja, or letters to the editor. It turns out that, despite the the difference in the issues addressed, there was also a universality of theme; emancipation in education rankly highly. The main issues addressed were cultural hybridity in language, customs and outlook. Compared to CSYP, in which only 26 articles had been written by women over a time span of 11 years, the letters of the enlightened Peranakan women outnumbered the figure in CSYP. More than one newspaper was willing to publish the letters, and the women made good use of this golden

13 However, another source said the editor was a certain Tan Soei Bing (Douwes Dekker 1909: 264). 
opportunity to make their voices heard.

One crucial issue about the letters is to ascertain that the authors were real women, and not a man disguised under a woman's name. It is a difficult task, since most of the authors are unknown to the general public, and information about them is non-existant. Nio Joe Lan (1962: 128) has warned of such practices, which are known as "literary masquerade". ${ }^{14}$ The first interesting feature is that, on many occasions, the letters were co-written by two, three or even four women. Usually they were sisters or otherwise related: "Nona Oei Sioe Nio - Sidhoardjo; Nona Oei Im Nio - Sidhoardjo; Nona Oei Tjwan Nio Sidhoardjo" (Oei Sioe Nio, Oei Im Nio, and Oei Tjwan Nio 1904). Secondly, the author(s) often declared that she was/they were the daughter (s) of Mr X in $Y$, giving a specified address. Two examples are "Dora Oei binti Tiang Seng (Soekaboemi)" (Oei binti Tiang Seng, Dora 1901)15 and "Nona Tan Siang Nio, Nona Tan Toei Nio, anak dari S.s. Tan Kim Kwe, Tjiampea, Buitenzorg, lid T.H.H.K" (Ms Tan Siang Nio, Tan Toei Nio, daughters of Mr Tan Kim Kwe, Tjiampea, Buitenzorg, member of the T.H.H.K) (Tan Siang Nio and Tan Toei Nio 1904). The father is the head of the family in patriarchal Chinese culture and mentioning his name meant that the father had given his permission. I regard this kind as 'the most guaranteed' type, since it would have been an embarrassment if the father had 'borrowed' his daughter's names. The trickiest are those written using pen-names, which means that the true identity of the authors has to be tracked down. An example is "Nonah Terate van China" (Ms Lotus from China) (Terate van China 1905). Nio Joe Lan (1962: 128) suggests that one possibility is that these women were too shy to give their real names and worried about any resultant criticism.

In closing this introduction, let me return to the case of Ms Tjoa Phik Nio from Besuki, East Java, whose contribution to the newspaper is praised at the beginning of this chapter. In 1906 she called upon her sisters everywhere to express their thoughts in the newspapers:

The motivation of all the women who often write in the newspaper, including myself, is not that [we] sought for praise by writing beautiful essays, but because [we] want to find the truth. Moreover it is the obligation of somebody who wants to broaden his/her knowledge on a page of the enlightened people's association, since not only can we have discussions with the well-known literati, but as well as that we can get a more perfect education than by studying at home all the time, isn't that correct, Mr Editor? (Tjoa Phik Nio 1906: 2, italics added.) ${ }^{16}$

14 On literary masquerades, see Taylor (1981).

15 Interestingly she uses Arabic word binti or "the daughter of'.

16 The original texts are as follows (italics added):

Bahwa maksoed saja dan sekalian orang prampoewan jang sering mengarang di soerat kabar, boekan lantaran maoe bereboet kapoedjian dengen kebagoesannja karangan tapi sebab hendak mentjari kabeneran, apa poelah di satoe halaman perkoempoelannja orang-orang jang berboedi itoelah memang wandjibnya [sic!] bagi saorang jang ingin meloewasken pengetahoeannja, kerana boekan sadja kita bisa beroendingan pada sastrawan jang namanja soeda termasjoer, lain dari itoe hanja kita bisa dapat peladjaran jang lebih sampoerna daripada kita beladjar di roemah sekola, boekankah begitoe sianseng Redacteur? 
She was a "new woman" who had discovered the benefit of newspapers as a public sphere in which she could find truth. Asking for legitimation from the editor, she states that newspapers offer more opportunities than just studying at home.

\section{DisCOURSES ON CHINESE WOMEN}

Since the women of our nation until today have still not emerged from the darkness, most still cling to conservatism and superstition; therefore they cause most of our nation to be reluctant to change their behaviour (Tjoa Phik Nio 1906: 2). ${ }^{17}$

Six years after the foundation of the THHK Batavia, a Peranakan woman complained in the newspaper about her sisters (bangsa kita prampoewan), whose consciousness has "still not emerged from the darkness". The Peranakan women had been sending their letters since as early as in 1901, when some had had their letters published in the newly founded paper, Li Po. This letter is an example of new stirrings which began to emerge in the early-twentieth century. Here I shall highlight discourses on Chinese women as they appeared as letters to the editors. However, because of restrictions on space, I focus only on two issues: attacks on hybridity towards an "authentic" Chinese identity and emancipation in education.

The first main discourse addressed by the letters was the rejection of hybridity, particularly the influence of local culture in various aspects of their lives. The goal before the eyes of these women was an "authentic" Chinese culture, even though they never clearly explain what they understood by the definition. Among existing hybrid cultures, betel-chewing tradition (kabiasaän mengoenjah sirie) is bitterly criticized by both enlightened men and women, on the grounds that it had been adopted from Javanese culture (adat biasanja priboemi bangsa Djawa). ${ }^{18}$ An anonymous woman argued that

[E]ating (chewing) betel has become less common in the twentieth century, which is called the modern age, and wastes time, wastes money, does not fill the stomach, makes the mouth dirty and smells bad [...] [T] herefore, it is important for our nation of female Chinese, who have already become accustomed to and followed the customs of the natives (Javanese) to gradually decrease this habit (again) until it disappears totally. ("Hal orang prampoewan" 1906: 2.) ${ }^{19}$

17 The original texts is:

Bangsa kita prampoewan hingga ini hari masi belom bisa sedar daripada kaglapannja, kebanjakan masih pegang tegoe pri kakoenoan dan tachajoelnja, pada mana membikin sebagian besar bangsa kita prampoewan djadi segan meroba itoe atoeran.

18 On the history of this practice, see Reid (1985: 529-47).

19 The original text is:

[...] makan sirie (mengunjah sirie) [...] koerang paedah boewat die djaman abad ka 20, jang dikata djaman kemadjoewan, dan boewang tempo, ilang wang pertjoema, tida membikin kenjang isie peroetnja, tambah bikin kotoer-kotoer moeloet dan koerang sedap baoenja [...] dari sebab itoe soepaja bisa diperhatiken pada bangsa kita Tiong Hoa prampoean jang soeda terlandjoer dan toeroet adatnja anak negrie (bangsa 
Betel-chewing was stigmatized as an "old-fashioned" custom, not of the modern age. As it was unhygienic, it had gradually to be eradicated. A certain Miss Oei Kok Nio questioned the existing etiquette for Peranakan girls paying a visit, namely: squatting and making a respectful greeting (berdjongkok dan menjembah). "Where did it come from? It is native custom (adat boemipoetra)", she asks rhetorically and then answers her own question. And she advises:

However, for this modern age, [the hybrid practice] must be replaced with an authentic protocol (which is used in China), i.e. whenever one [lady] meets another [they] must pay respect to each other (Oei Kok Nio 1906: 2). ${ }^{20}$

For bangsawan prampoewan like Miss Oei, two things urgently needed to be done: to eradicate hybridized culture and to adopt authentic Chinese culture (adat jang berlakoe di negri Tjina), a befitted modern women. To legitimize this cultural shift, Miss Oei decides to use a saying from the Analects of Confucius: "When there is a fault, it is better to amend it quickly" (maka djika ada salah, baik lekas-lekas aken merobah). ${ }^{21}$ To lend her advice an even stronger not of authenticity, Oei Kok Nio provides the saying in three languages and two scripts: Romanized Malay, Romanized Hokkien and Mandarin in Chinese characters. This impressive multiplicity of languages and scripts was something new. ${ }^{22}$

"Hybrid", originally a term referring to the cross-breeding of two species by grafting or cross-pollination, takes many forms: linguistic, cultural, political, racial, etcetera ("Hybridity" 2000: 118). The bangsawan prampoewan's attack on hybrid practices might be explained by what Nikos Papastergiadis describes: "Whenever the process of identity formation is premised on an exclusive boundary between 'us' and 'them', the hybrid, born out of the transgression of this boundary, figures as a form of danger, loss and degeneration" (Papastergiadis 2000: 259). He continues: "for as long as the concepts of purity and exclusivity have been central to a racialized theory of identity, hybridity has, in one way or another, served as a threat to the fullness of selfhood. The hybrid has often been positioned within or beside modern theories of human origin and social development, mostly appearing as the moral marker of contamination, failure, or regression" (Papastergiadis 2000: 257). Therefore, one of the main agenda points of enlightened women was

Djawa) soepaja dengan pelan (dikoerangin lagi) sampe tidak sama sekalie.

20 Original text: Akan tetapi boeat ini djaman kemadjoean, haroes dengan terganti adat jang sedjati (adat jang berlakoe di negri Tjina) jaitu djika bertemoe satu sama lain mesti melakoeken Liam Djin.

${ }_{21}$ James Legge's translation, and widely cited is: "When you have faults, do not fear to abandon them", (http://www.sacred-texts.com/cfu/conf1.htm, accessed on 7-11-2016).

22 The majority of Chinese women in the Indies used Malay or the vernacular as a daily medium, with the exception of those living in West Borneo, who still maintained their dialects. In the late-nineteenth century the prominent Dutch sinologist Gustaaf Schlegel confirmed that "no Chinese women in Java speak Chinese" (Schlegel 1891: 148). In the 1930s it was reported that the peranakan ladies of Makassar (South Celebes) were more familiar with Makassarese script than the alphabet; see Lie (1932: 306). Apparently, within fifteen years women had taken giant strides in learning new languages and scripts. 
to eliminate any hybrid practices, since they represented this sort of "moral marker". Did the migration of women from China also play any role in this gendered "purification" movement? ${ }^{23}$ If not, where did the inspiration for an "authentic" Chinese woman come from? More research is needed to answer these questions.

The other crucial issue, which appears from time to time, is that of equality of education for women. Several letters address this issue, but I shall just summarize a letter from Siotjia (Hokkien = Miss) K. Lim. She criticizes the conservatism of Chinese parents on the subject of the cloistering their daughters from the age of twelve or thirteen (dikoeroeng dalem roema) as discussed above. The parents were not bothered about whether the daughter still wanted to study, or had completed her studies. The reason was that they were afraid that she would be pestered by boys (kena goda anak lelaki). Ms Lim denies that a "civilized man" (satoe lelaki jang kenal adat sopan) would behave in this manner, and hopes that this bad practice will be abandoned by the Chinese (itoe adat djelek tiada melengket lebi lama poela di antara bangsa Tionghoa) (Siotjia K. Lim 1909: appendix).

The women who were fortunate enough to receive a modern education and had mastered romanized Malay saw the opportunity offered by the flourishing Malay newspaper industry. Even though they used non-standardized Malay, written in remarkably prolix sentences, they managed to create a gendered public sphere. Their ability to propagate their ideas in the public arena in the newspapers was something that differentiated them from their mothers.

\section{"A SIGN OF MODERN TIMES": PERFORMERS OF WESTERN CLASSICAL MUSIC}

Until the early-twentieth century, Chinese girls in Java were relatively invisible because they should not be seen in public until the day of their marriage. Young Peranakan girls were supposed live in seclusion (Malay: dipingit) (End 2006: 15). They would not dare to receive guests and were only permitted to go out to celebrate such outdoor festivals as pasar malam (night fair) and Cap Go Mèh (the end of Chinese New Year, which was celebrated a host of many festivities). However, these outings was only permitted late at night, when there were fewer people around. Girls and young women could attend wedding and New Year celebrations, but once again, they should be kept away from men's sight, and had to help the older ladies in the kitchen (membantu di dapur) (Tio Tek Hong 2006: 19; Campbell 1915: 1099).

In this atmosphere of protecting chastity, those who performed before the

23 Liem Thian Joe (1933: 90) reported that, around 1815, there were only one or two women from China, who were mistresses of local wealthy Chinese, living in Semarang (Central Java). The price for the women was extraordinarily high and only certain gentlemen could afford to pay for them. "Authentic" Chinese women with bound feet and wearing trousers attracted their fair share of curiosity from peranakan women. They were called "njonja negoro Tjino'" (ladies from China) in Javanese. Female immigrants from China had begun to arrive in the Indies in substantial numbers by the end of nineteenth century. Unfortunately, in contrast to the Straits Settlements, the Dutch did not specify the gender of Chinese immigrants. The procedure of the former makes it much easier for scholars to study the topic. 
public, actresses in the traditional Chinese opera or other forms of popular theatre, were seen by the people as little more than public courtesans, much as they were in traditional China (Borel 1907: 1062). In 1891, a Chinese opera troupe which performed in Surabaya was criticized for "being dirty and disturbing the peace in the neighborhood where they were staying" (Cohen 2006: 57). A newspaper published in Batavia in 1902 commented that performers of the Chinese opera were "viewed as lowly and contemptible and there is no Chinese of good background who mixes with them" (Cohen 2006: 57). This antipathy had its roots in the earlier part of the nineteenth century, when the majority of Chinese opera troupes were female. Performers were often not of Chinese descent. They were usually Southeast Asian women drilled and trained to a high degree of proficiency by teachers imported from China (Cohen 2006: 8). It was then a common practice in Java that those actresses were "for the most part mistresses or sex workers at the disposal of the troupes' owners for their own pleasure, the pleasure of their friends, or for profit". Therefore, it was not surprising that performers suffered from venereal disease and abuse (Cohen 2006: 57). To display their prosperity, wealthy Peranakan Chinese officers would keep an all-female opera troupe. There were four of these kinds of troupe in Batavia in the 1850s; that owned by Majoor Tan Ing Gwan being the most famous. It was rumoured that most of the performers, including its prima donna, Bweehoa, were the Majoor's mistresses (Cohen 2006: 56-57, 399).

Troupes from South China occasionally visited port cities in the Indies which had substantial numbers of Chinese inhabitants. Once, when a Cantonese troupe ${ }^{24}$ was visiting Semarang, one of its actresses "had caused havoc amongst the men because of 'her lovely face and complexion'" (Rensselaer Thayer 1943: 84-85). Interestingly, this same Cantonese lady was hired by the prominent Semarang business magnate, Oei Tiong Ham, to be a private tutor in Chinese traditional music for his daughters Oei Tjong Lan and Oei Hui Lan. However, as recalled by Hui Lan, "her presence in our house caused no end of lifted eyebrows among Mama's family and friends, for actresses were not considered respectable in those days" (Rensselaer Thayer 1943: 85). ${ }^{25}$

Jan Lambrecht Zegers (1844-1911), a Dutch missionary, could not hide his dissatisfaction with the Chinese families' practice of secluding their daughters. This "very sacred" custom decreed that a Chinese girl would be despised by her own people if she did not follow the tradition. In a conversation with Peranakan parents in West Java in 1879, he received a "challenge" from the Chinese: "We shall gladly stop the custom but we only dare to take this step after it has been pioneered by a wealthier and more influential person than

24 The Cantonese opera was very popular, but rather expensive to watch in late-nineteenthcentury Singapore. Apparently, the ticket price cost more than that of the Hokkien and Teochew troupes (Pitt Kuan Wah 1988: 26). Probably the Cantonese opera was more sophisticated in its performances.

${ }_{25}$ It is interesting that Oei Tiong Ham, who had Hokkien roots, hired a Cantonese music teacher. 
a member of our congregation." He was powerless and all he could do was "be patient" and hope that time would usher in a change (End 2006: 199, 278).

Zegers' story reflects the message that only a wealthy Chinese could be a potential reformer in emancipation for women. Thirty years later, this role was fulfilled by the millionaire-cum-philanthropist from Semarang, Oei Tiong Ham (1866-1924). ${ }^{26}$ Perhaps through his business contacts with Europeans, Oei had become acquainted with western classical music and, to show the liberality of his outlook and the fact that he could emulate them, besides Chinese music, Oei also decided to have his daughters taught the skill of the masters' art. He first commissioned a British governess - a certain Miss Jones - to teach his daughters western classical music and European languages (see below). To learn music on a more advanced evel, Oei later sent Gwendoline (Oei Tjong Lan, 1886-?) and Angèle (Oei Hui-Lan 1889?-1975) ${ }^{27}$ to Singapore where they took piano and vocal lessons with the well-known Madame Bassett-Arrall around early 1905. It must have been challenging for her to teach western classical music to young oriental ladies.

On 6 December 1905, the pupils of Madame Bassett-Arrall gave a concert at the Old Town Hall, attended by the Governor of Singapore, Sir John Anderson and his suite. Gwendoline and Angèle, with other students, performed compositions by such famous composers as Charles Gounod and Gabriel Faure. I suspect they were the only two non-Europeans among the students. Therefore, their performance was keenly observed, and they did succeed in captivating the audience: “Two Chinese young ladies, the Misses Gwendoline and Angela H. Oei, sang as a duet Faure's 'La Charite' and the timely blending of their voices, sweetly modulated, came as a delightful surprise to all present." The press concludes that the duet "was a novelty to Singapore, we might say a startling novelty" ("Madame Bassett's recital" 7-12-1905: 3). However, the jewel of the performance was Angèle Oei Hui Lan:

The three cornered novelty of a young Chinese girl singing in French to an English audience in a Malay country next occupied the attention of the audience. This was "Farfalla" by Ms Angela H. Oei. Her effort captivated the audience, and but for the fact that encores were not allowed she would most certainly have been recalled. We have attended recitals great and strange in three capitals of Europe, but we must admit that this, the song of Miss Angela Oei staggered us. We repeat the novelty in a nutshell: a Chinese girl from Sumatra [sic!] singing a French classic in French to an English audience. Surely this is a world's record! Is the East, after all, so far apart from the West? ("Madame Bassett's recital" 7-12-1905: 3.)

\footnotetext{
26 Oei Tiong Ham was born in Semarang to a China-born father. One of his main earlier businesses was opium, from which he made enormous profits. Later he focused his core business interests on sugar and rice. Besides being a millionaire, Oei Tiong Ham was also a famous philanthropist, who donated a huge amount of money to schools in the Netherlands Indies and Singapore (Kunio 1989).

27 I am grateful to Peter Post for helping me to identify Oei's daughters. Angèle is written Angela in British press.
} 
It is not surprising that the recital was regarded as "one of the enjoyable entertainments ever held in Singapore" ("Madame Bassett's recital" 7-121905: 3). Performing in public was, naturally, a spectacular achievement for Chinese ladies elsewhere in Asia during the early-twentieth century. Through their mastery of western languages-cum-music, the Oei sisters, successfully emulated the Europeans and made history in the region. ${ }^{28}$

Their successful overseas debut convinced Oei Tiong Ham to let his daughters perform in his home town. In March 1907 Angèle gave a vocal recital in Semarang, a soirée musicale, in the THHK school building in a fund-raiser for the school. ${ }^{29}$ She was accompanied by her sixteen-year-old niece, Lim Tshoen, from Singapore and her twelve-year-old nephew, Arthur Lim, on piano. ${ }^{30}$ Angèle performed pieces by French composers: Charles Gounod ("Siebel" in Faust) and Georges Bizet (from the opera Carmen) in elegant, fluent French. Henri Borel, the government's Chinese translator and a well-known author, was a member of the audience and applauded the performance warmly:

A Chinese concert, but totally of European music, performed by two young Chinese girls and one young Chinese boy of just twelve years, is surely a sign of modern times, which everyone's attention was fixed on (Borel 1907: 1062, italics added).

While affirming his belief that this performance was a signifier of modernity among Chinese girls in the Indies, Borel added that such activities were considered "shocking" and "indecent" by many in the Peranakan community. These factors were probably the main reason their first performance, Borel thought, had been given outside the Indies.

Two years later, the Oei sisters appeared on stage in Semarang for the first time. This time they were accompanied by two girls from a prominent family in that city. They were Caroline Valentine Tan Souw Lien ${ }^{31}$ and E.V. Tan, daughters of Mr Tan Toan Soen. ${ }^{32}$ Under the guidance of an opera specialist,

28 The news of the successful performance also reached the European press in the Indies, which commented that Oei sisters had been "awarded exultant praise" by the Straits papers (Borel 1907: 1062; “Wat de Chinees Vertelt" 15-4- 1909: 5).

29 Oei Tiong Ham was well known for his sympathetic ideas about education. He donated generously to all the THHK schools in Central Java, in which "his name is always on the top list of the benefactors'" (Liem Thian Joe n.d.: xiii). Oei also donated money to educational institutions abroad, for instance, in Singapore. Furthermore, he donated $\$ 10,000$ [straits dollar] to the Tao-nan School, the first Mandarin school in the British colony, as well as to Raffles College and Convent.

30 Lim Tshoen and Arthur Lim were the children of Oei Tiong Ham's younger sister, who married Liem Ik Khing (Song Ong Siang uses the Straits' pronunciation Lim E Ging). He was the manager of Kian Gwan, Oei Tiong Ham's company in Singapore (Liem Tjwan Ling 1979: 12; Song Ong Siang 1967: 353).

31 For more on this remarkable lady, see the end of this chapter.

32 He was born in Bangkalan (Madura) and married the daughter of Semarang's Lieutenant Liem Tjoe Tjiang. In 1907 he became a naturalized Dutch citizen, something which could only have been achieved by an extraordinary non-Dutch person ("Wat de Chinees Vertelt" 1-4-1909: 5; Liem Thian Joe 1933: 151). 
Mrs C.G. van den Steen, ${ }^{33}$ they performed a soirée variée at the Schouwburg, raising funds for the destitute earthquake victims both in Messina (Sicily, Italy) and in China. The quartet sang well and, besides songs from Western repertoires, they also performed a short tableau, "The fan of young China" (Kipas dari Tiong Kok moeda), in which the girls were arranged in the shape of a fan. The stage was decorated with the Dutch and Chinese flags. This concert by the daughters of orang hartawan (wealthy people) was very successful and raised the total sum of 4,588 guilders ("Wat de Chinees Vertelt" 15-4-1909: $5)$. The success of the Oei ladies and the reception they received encouraged ladies from other prominent families to follow suit. In 1908 the daughters of the $\mathrm{Han}^{34}$ and Liem families, the élite Chinese families in Surabaya were also eager to display their talent.

The Oei sisters' success should be credited to their progressive parents, Oei Tiong Ham, who was consistently obsessed with modern things, and their long-suffering but ambitious mother Goei Bing Nio. ${ }^{35}$ Instead of sending them to a public school, Oei hired expensive private governesses for Tjong Lan and Hui Lan. They first acquired fleuncy in French, taught by a Belgian governess, and later learned English from Miss Elizabeth Jones, a British lady, and Chinese [dialect?] from the remarkable Cantonese actress mentioned earlier. Therefore, "being multilingual is a natural way of life to me", confessed the exceptional Angèle Oei Hui-Lan (Koo and Taves 1975: 63). ${ }^{36}$ As well as English, Miss Jones also taught Western etiquette and music (piano, ballet, and ballroom dancing) (Rensselaer Thayer 1943: 80-85). ${ }^{37}$ Therefore, it was not surprising that, as early as 1902, the Oei sisters were already famous and had won unstinted admiration from the educated women in the Indies, as reflected in a letter from the progressive Javanese noblewoman, Raden Ajeng Kartini (which will be discussed at the end of this essay).

33 She led Surabaya's foremost amateur theatrical club, the Vereeniging Apollo, and the tableau vivant was her specialty. She seems to have been quite a remarkable person, since a handsome sum of 8,000 guilders was spent to illuminate her tableaux with focused light in Surabaya's Schouwburg in 1883 (Cohen 2006: 404 note 154).

34 On the origins of the remarkable Han family, see Salmon (1991: 53-87).

35 Goei Bing Nio, the first wife of Oei Tiong Ham, felt neglected by Oei Tiong Ham because she could not bear a son to him, an important achievement in a patriarchal society like that of the Chinese. "[...] Poor Mamma. She had so much beauty and pride and burning ambition [...] She would have loved sons, taken as much or more pleasure in them than in her daughters. But we were all she had, so she poured her dreams and ambitions into us. Her one aim in life was that we would marry brilliantly and so reflect credit on her". (Koo and Taves 1975: 58, italics added.)

36 Angèle Oei Hui Lan was later known by many names: Countess Hoey Stoker, Hui-Lan Koo, and most widely known of all: Madame Wellington Koo. She sparked controversy in the region when she married a westerner, Caulfield Stoker, an Irishman who worked as the American consular agent in Semarang in 1909 (The Straits Times 10-11-1909; Godley 1981: 49) but her first marriage was unsuccessful and they divorced in 1920. A year later Hui Lan married China's ambassador to France, the United States, and Great Britain, the brilliant V.K. Wellington Koo (1887-1985). Before the age of the popular entertainment industry, Hui Lan perhaps was the first transnational celebrity from the Malay Archipelago ("Wat de Chinees Vertelt" 2-12-1909). ${ }_{37}$ When Miss Jones first arrived, as the girls did not understand English, French became their mutual language (Koo and Taves, 1975: 62). 


\section{MODERN GIRLS FROM SURABAYA}

And I blush to rebate

That he taught Japan's fair daughter

To flirt and kiss

Like the little white Miss

He call'd her the Jewel of Asia-of Asia-of Asia

But she was the Queen of the Geisha-the Geisha-the Geisha

(Hashimoto 2005: 108.)

Carrying a parasol and a fan, O Mimosa San, a young lady clad in a colourful kimono, sings from the heart. She is the favorite geisha from a teahouse, who is referring a to a British naval officer who had fallen in love with her. The scene was neither in Japan, the home of the geishas, nor on the West End stage in London. It was in Surabaya's prestigious Schouwburg. That night in October 1908, the concert hall was crowded with a mixed European and Chinese audience. Who was O Mimosa San? She was the leading figure from "The Geisha", a British operetta composed by Sydney Jones in 1896, when the oriental craze had the West firmly in its grip..$^{38}$ That night the beautiful Jeanne Han Tjong Tie (Figure 3), a local Peranakan girl, was the prima donna, who interpreted the role of O Mimosa San. Her acting, voice and correct English pronunciation elicited warm applause from the audience (Ezerman 1908: 524).

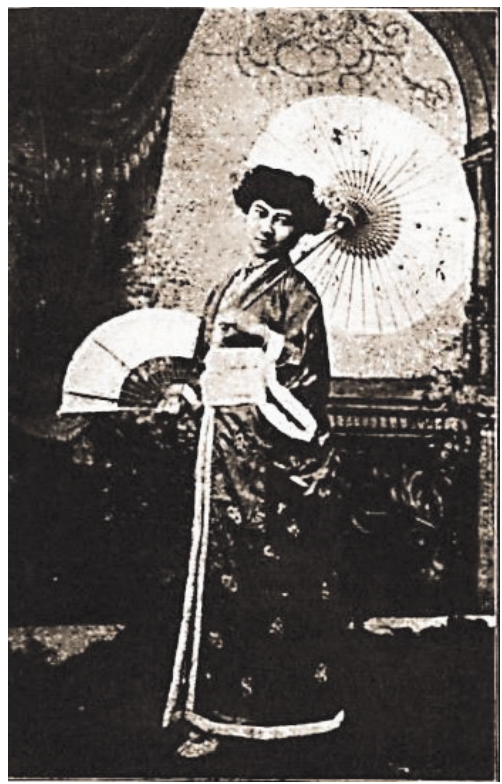

Figure 3. Ms Jeanne Han Tjong Tie in Japanese kimono (source: Weekblad voor Indië 18-10-1908).

38 The complete title of this play is "The Geisha, a story of a tea house", text by Owen Hall, lyrics by Harry Greenbank and music by Sydney Jones. The première was held in London, April 1896 ("The Geisha" 2001: 731). Actually, it was "the first internationally successful British musical", performed in West End 760 times between April 1896-May 1898; even more than the famous The Mikado (1885) by Gilbert and Sullivan. Yorimitsu Hashimoto (2005: 105) argues that this operetta was responsible for the spread of the word "geisha", which became synonymous with ideas about Japan and the Japanese. 
Under the supervision of Mrs C.G. Van den Steen (see above), the Dutcheducated Peranakan girls Antonia Han Siau Gwan, Josephine Liem Sian Tjay, Jeanne Han Tjong Tie, and Anna Liem Sian Tjay performed "La Craquette" (the Stork), a song popularized by the Band of H.M. Scots Guard (Figure 4). They were followed by Anna Liem Sian Tjay, Rosa Tio Siek Giok, Josephine Liem Sian Tjay, and Noes Lie Khai Tjiang who performed the "Spanish Dance" in gypsy dress (Figure 5). The climax of the show was reached when all the girls appeared in kimonos and performed "The Geisha". This operetta was a big hit in Europe, including the Netherlands ("The Geisha" 2001: 733), which prompted Mrs Van den Steen to have it performed in the Indies. The show was greeted with rousing applause by the audience.

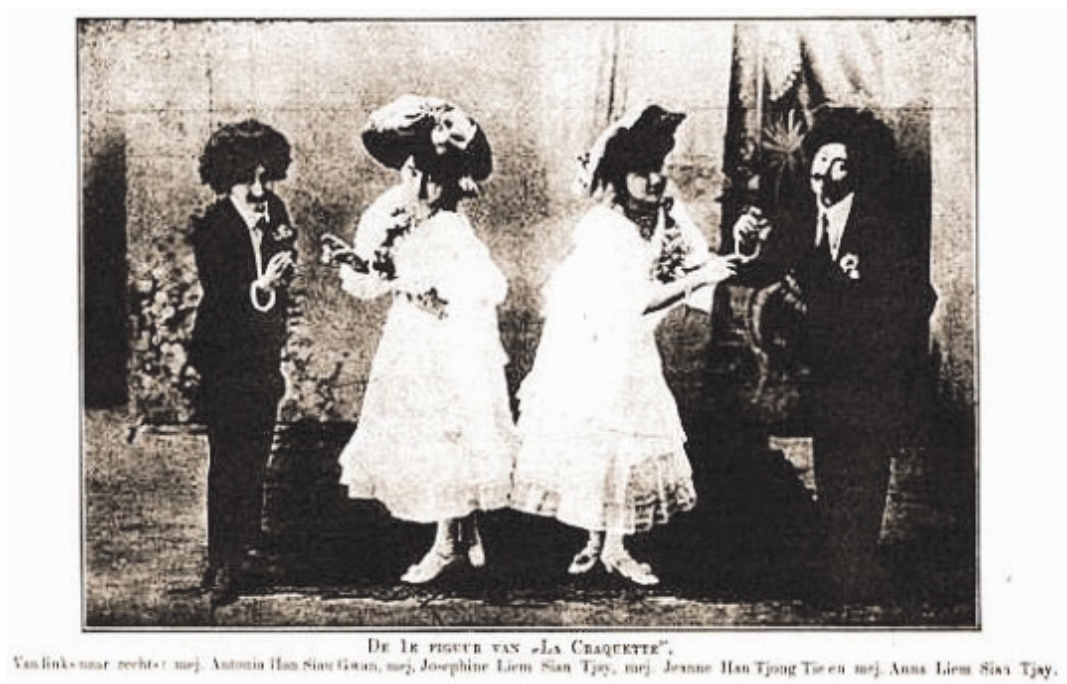

Figure 4. A group of Chineesche Belles from Surabaya in western fancy dress performing "La Craquette". Left to right: Antonia Han Sian Gwan; Josephine Liem Sian Tjay; Jeanne Han Tjong Tie; Anna Liem Sian Tjay (source: Weekblad voor Indië 18-10-1908).

Profiting from the miraculous new technology of printing, the photographs of those Chinese belles in various kinds of fancy dress, from Spanish gypsy to Japanese kimono, were printed in the popular Dutch-language magazine published in Surabaya, Weekblad voor Indië (Figures 3-5). It should be noted that illustrated magazines with photographs were still a new invention in the early-twentieth century. ${ }^{39}$ And since photography was able to supply a visual representation of the modern activities of the enlightened women, surely it must have had a big impact on Chinese and non-Chinese alike, whether pro or contra.

39 There were at least two prominent periodicals which used photographs: Weekblad voor Indië (in Dutch) and Bintang Hindia (Malay and Dutch). However, the latter was much superior in the quality and quantity of its photographs. 


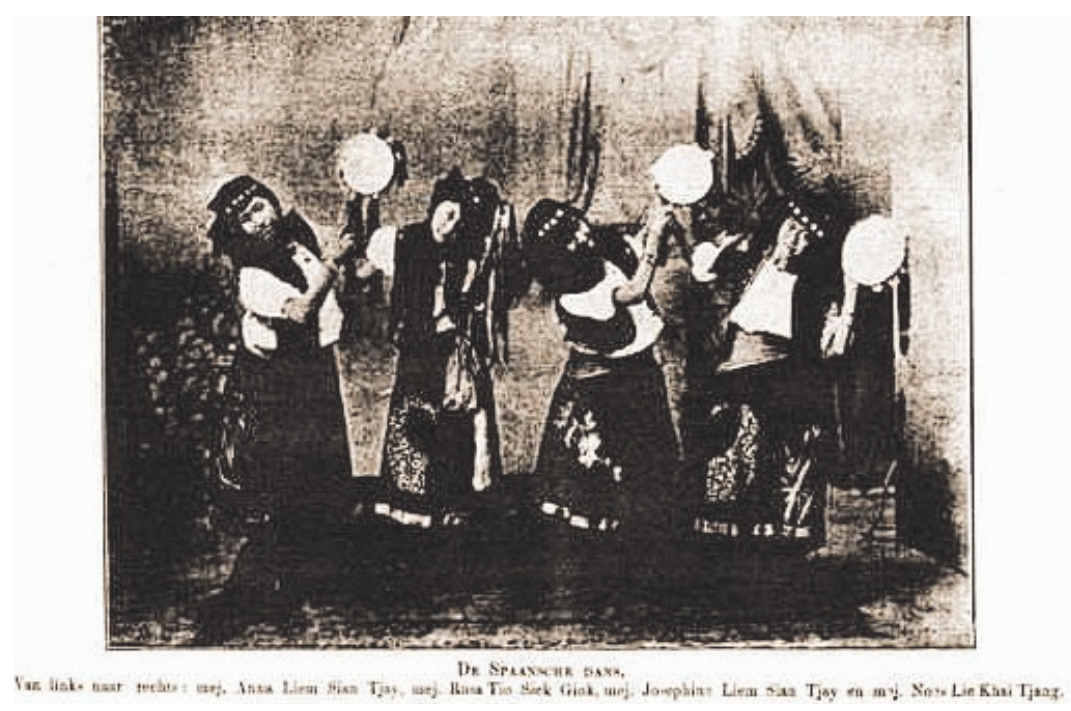

Figure 5. Bangsawan Prampoewan from Surabaya in gypsy dress. Left to right: Anna Liem Sian Tjay; Rosa Tio Siek Giok; Josephine Liem Sian Tjay; and Noes Lie Khai Tjiang performed "Spanish Dance" (source: Weekblad voor Indië 18-10-1908).

Commenting on their talent, a western spectator said that the bangsawan prampoewan's "sense of taste and beauty are not inferior to those of their European sisters" (Ezerman 1908: 524). Powered by the undimmed energy of Mrs Van den Steen, this gala performance was "something new and enjoyed glorious satisfaction", because "there was intelligence, there was emotion, there was talent in the text, singing and poetry" (Ezerman 1908: 524). Reaffirming Henri Borel's remarks on modernity, the author wrote "We are convinced that Chinese youth [the Chinese kaoem moeda] is passing through an evolution. In this turnabout, from time to time in the kingdom of undeniable beauty, this evolution should be regarded as a blessing" (Ezerman 1908: 524). The Chinese kaoem moeda was now no longer a male-dominated enterprise; it had also shown a feminine face in public.

Actually what the ladies had ventured was not entirely new. About thirty years earlier, Dutch writers had already noted how westernized the The-family from Surabaya was. M.T.H. Perelaer (cited in Onghokham 1982: 290) reported that, in 1870s, during a Chinese feast in the The-house "there was Western music and ball-room dancing in which the The-daughters participated". How was this possible? There might be several answers. The specific character of the place concerned might have been part of the answer. Surabaya was always famous for its cosmopolitanism. It is important to remember that the women's achievements were not the result of their own efforts per se. Apparently fathers or husbands set their own agendas in this modernity project (Paul Tickell, personal communication, Jakarta 4-3-2004). A modern daughter or wife meant that prestige would accrue to the father or husband, since they were deemed enlightened enough to grant their loved ones freedom of expression. The father-daughter relationship, as shown in Joanne Poon's study of the "Miss 
Queen of Cathay" contest among the Chinese of Vancouver in the 1950s, could have been another possibility. She discovered that "the more heavily the father was involved in the association business and the community at large, the more his daughter felt that she was obliged to represent the association to which the father belonged [...] Traditionally, girls were expected to obey their parents, particularly their father" (Poon 1997: 130). In Oei Hui Lan's case, Oei Tiong Ham was closely involved in THHK movements and therefore it was natural for her to do her best to raise funds for the THHK "on behalf of her father".

What the Chineesche Belles in Java attained was a truly outstanding achievement, much ahead of their time compared to the Chinese overseas communities elsewhere, either in the Straits Settlements or, probably, even the United States. The photograph caption of Miss Chinatown of San Francisco in 1958 claims "just 35 years earlier [1920s], no respectable Chinese lady would allow herself to be seen in public" (Hall 1998: illustration page). There were also various signs of westernization among the bangsawan prampoewan. We learn that all the Chinese ladies, from either Semarang and Surabaya, had adopted Western names; French ones seemed quite popular. Moreover, it was obvious that the French language and western classical music had become trendy among the wealthy Peranakan families; providing a person with the emblems of their modernity. These Peranakan were all very cosmopolitan and well informed. On the downside, the westernization of the kaoem moeda's cultural life did perhaps distance them from the masses. In the 1930s it was reported that most Peranakan were still largely lovers of the Javanese gamelan and of Indies keroncong music (Kwee Kek Beng 1936: 87).

\section{TOWARDS A GENDERED SOCIAL CHANGE}

By the end of the period of Dutch colonialism, a rapid social change had occurred among Peranakan parents and their daughters, directed towards a "Dutchification". The official education report of the Netherlands Indies of 1939/40 shows the number of girls attending Dutch-Chinese schools to be about $10,000,45 \%$ of the total student population of 22,000 (Govaars-Tjia 2005: 256). ${ }^{40}$ In 1911, the sympathetic Dutch lawyer P.H. Fromberg (1926: 503) had complained that not enough girls were attending many Chinese schools because parents were afraid that, when the educated daughter married, her attitude towards her spouse might be overconfident. In the earlier part we have already noted missionary complaints from the nineteenth century grumbling that parents were too conservative with their daughters. However, a major shift towards equal opportunity in education did occur in Chinese families, in which the early-twentieth century as the crucial watershed.

In 1910, or two years after the HCS was established, there were 2,700 Chinese school children studying in a total of 17 schools, of whom 761 were female students. In the same year, 300 boys and 200 girls were attending

40 Unfortunately, I cannot locate figures of Chinese female students at various private Chinese schools. 
European private schools ("Een Chineesche Vereeniging" 1913: 246; “Wat de Chinees Vertelt" 28-5-1914: 7). The wave of modernity proved unstoppable. Four years later, a young Peranakan woman, Tan Soekoe Nio, succeeded in becoming the first Chinese vaccinator ("De Eerste Chineesche Vaccinatrice" 11-6-1914: 1). Caroline Valentine Tan, alias Tan Souw Lien from Semarang who was mentioned earlier, graduated as Meester in de Rechten (LL.M.) from the University of Utrecht in 1923. She may have been the first Peranakan Chinese woman to qualify as a lawyer (Liem Thian Joe 1933: 151; Coppel 1997: 25). ${ }^{41}$

The foundation for the rapid social change was built at the beginning of the twentieth century by enlightened parents, supported by the bangsawan prampoewan themselves: those who were articulating their dreams, hopes and ideas as authors or performers, particularly Oei Tiong Ham's daughters and the belles chinoises from Semarang and Surabaya.

\section{"HURRAH FOR PROGRESS!": CHINESE WOMEN AS INSPIRATION}

On June 1902, a Javanese lady wrote a letter brimming with excitement to her pen-friend in the Netherlands, praising what she considered to be the emergence of a new generation of Chinese girls

I read in the paper that some Chinese girls had asked permission to stand for the teachers' examinations. Hurrah for progress! I feel like shouting aloud in my joy. Of what good is the preservation of a few old traditions? We see now that the strongest and oldest traditions can be broken; and that gives me courage and hope. I should like to meet the gallant little Chinese girls; I should be so glad to know something of their thoughts and feelings, their 'soul' (Kartini 1964: 172-173). ${ }^{42}$

Chinese culture is considered by Javanese to be even older and more resilient than their own, since they regard the Chinese as coming from the older "ashes" (Javanese: $a w u$, refers to civilization) (Carey 1984: 3). Therefore, if even the restraints of this culture could be broken, nothing could be seen as eternal and immutable.

In an earlier letter written to her "spiritual mother" in January 1902, the same young woman wrote with fascination about the western-educated daughters of "a wealthy Chinese in Semarang", with whom we already familiar:

41 Although Liem Thian Joe (1933: 151) claimed that Caroline Tan is the first Chinese female lawyer, but Charles Coppel (1997: 26 note 4) doubt it. Hagen (1997: 114, 124 note 21) mentioned in 1915 a Chinese woman had graduated as a lawyer, and this news was discussed among the enlightened Javanese woman's circle. But this fact needs to be studied further (see further at the end part of this article). Peranakan man succeeded much earlier in this field. In 1888, a remarkable Oei Jan Lee from Banda Island had successfully graduated from the Law Faculty of Leiden University, and made him the pioneer (Poeze 1986: 37).

42 At this moment I am unable to disclose the Chinese girls' identity. 
It is generally said the daughters of the millionaire leader, Oei Tjing Ham [sic!], are highly cultivated ladies. They are said to speak modern languages fluently. It is said that one of these girls wants to go to Europe to study to be a lawyer. (Jaquet 1989: 219.)

Later in the year she repeated this story to the same person, demonstrating the depth of her admiration of the girls (Coté 1992: 350). ${ }^{43}$ Indeed, as we discussed earlier, Oei Tjong Lan and Oei Hui Lan, spoke western languages fluently, the key requirement for being accepted as a "civilized" subject in the early-twentieth century.
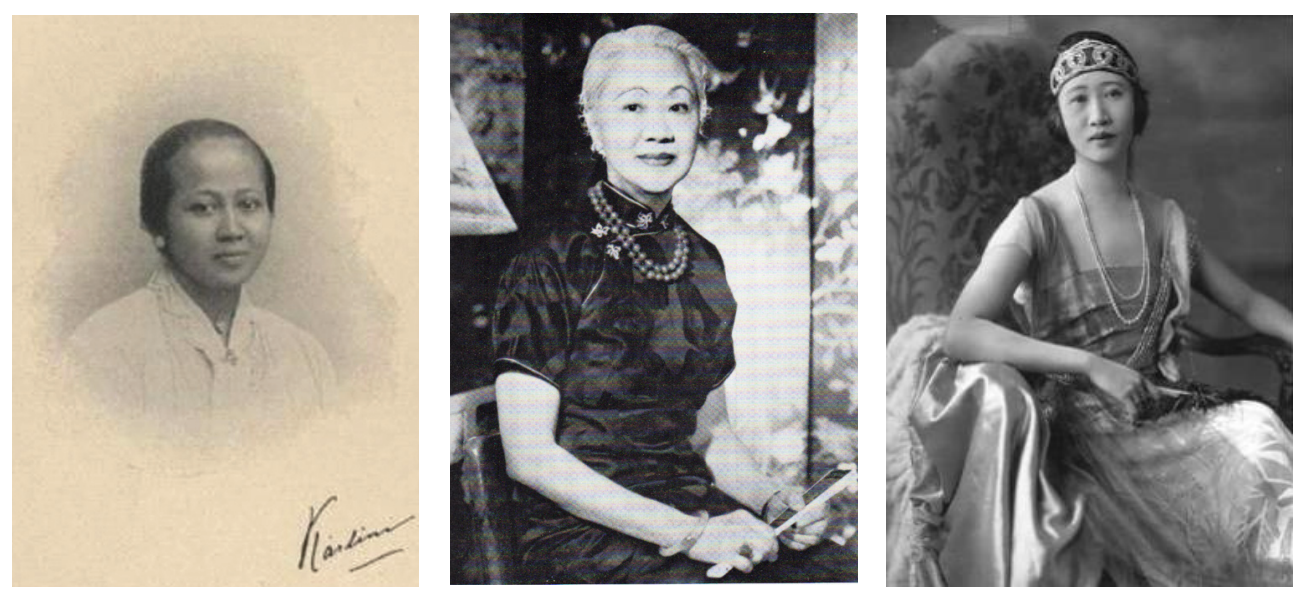

Figures 6-8. The Inspired and the Inspirers. Raden Ajeng Kartini (left), Oei Tjong Lan (middle), and Oei Hui Lan (right) (sources: http://hakimtea.com; Koo and Taves 1975: no page number; http:/ / thestar.com.my).

The author of those letters was none other than the famous Raden Adjeng Kartini (1879-1904), an enlightened noblewoman from Jepara, who had to live confined to a traditional cloister when she reached her adulthood. She struggled tirelessly for the emancipation of Javanese women, who were in a weak position during colonial times, and advocated equality of education and opportunity. Kartini's name became widely known after her letters were posthumously edited by her Dutch mentor, Jacques Henry Abendanon (18521925), and published in the Hague in 1911 under the title Door duisternis tot licht; Gedachten over en voor het over en voor het Javaansche volk (From darkness to light; Thoughts on and for the Javanese). In 1964 she was given the accolade of national heroine and has since become an icon of the modern Indonesian woman. In her short but fruitful life, Kartini established a school for Javanese

43 While admiring Oei Tiong Ham and his modern family, Kartini added "everyone knows that family except us". In the earlier part of the same letter, she lamented that her father did not allow her to build any relationships with the Chinese. Kartini took a sympathetic view of the Chinese - calling them "this unfortunate and despised people"- and praised Chinese charity towards the indigenous people who suffered from natural disasters and famine. She "would also like to get to know that [Chinese] people without prejudice" (Coté 1992: 349-350). 
girls, and promoted handicrafts made by Javanese. Nevertheless, her most important legacy is the correspondence with her friends in the Netherlands, in which she communicated her ideas about progress and emancipation.

Besides their modern educational achievements, Kartini noted that Oei Tiong Ham's daughters were also engaged in charitable works. In December 1902, she wrote that alongside their father, Oei's daughters donated lorries loaded with rice to the poor in Semarang through the government channels. This conformed with Kartini's definition of the "modern girl", ${ }^{44}$ whom she had so longed to meet. What the modern Chinese girls who were her contemporaries achieved, such as applying to train for respected professions like teacher and lawyer, added ammunition to her armoury to boost her struggle. Undeniably, it was the Chinese bangsawan prampoewan who made Kartini happily shouted: Hoera!, voor den vooruitgang! "Hurrah for progress!" (Kartini 1912: 206). In pursuit of these ideals of emancipation, Kartini saluted progress, particularly in these Chinese girls, for breaking what she considered "the strongest and oldest tradition" with the hammers of modernity. However, she did not forget to acknowledge (twice) that Oei Tiong Ham was also a modern father, who treated his daughters fairly in terms of their access to modern education.

Other activities of the enlightened Peranakan women's achievement were paid great attention in the Malay press. When a Chinese woman planned to continue her studies in Holland, graduating as a lawyer in 1915, a member of a Javanese women's organization, Wanito Oetomo wrote: “[...] Here is proof of the progress of Chinese women. How will be the course of progress of our native women proceed?" (Hagen 1997: 114, 124 note 21). ${ }^{45}$ Three years earlier Soenting Melajoe, a woman's newspaper from Minangkabau (W. Sumatra), published an article by Noerläla Anwar on "the improved rights of Chinese women". In 1917 the same paper reported the speech by Mrs Yap Hong Tjoen (LéonieTan Souw Lian) before distinguished audiences in the Hague (Hadler 2008: 148).$^{46}$ News about the Peranakan women students in the Netherlands reached not only their sisters in Java, but was also covered in the Indonesian press in Sumatra, and probably in any other places in the Archipelago. Undoubtedly they became an inspiration for Indonesian women to achieve higher education, even in overseas universities.

The enlightened Chinese were one essential movement in early-twentiethcentury Java, catalyzing the majority to emulate their restlessness in their quest for modernity. However, so far no single study of this movement and its people has appeared. This is rather surprising in view of how important their influence

44 Kartini defines a "modern girl" as "the proud independent girl [...]; who confidently steps through life, cheerfully and in high spirits, full of enthusiasm and commitment, working not just for her own benefit and happiness alone but also offering herself to the wider society, working for the good of her fellow human beings" (Coté 1995: 23).

45 I still could not disclose identity of the woman. See also footnote 41.

46 Léonie Tan Souw Lian (the first Mrs Yap Hong Tjoen) is the elder sister of Caroline Valentine Tan Souw Lien. Caroline married the well-known Dr Yap Hong Tjoen after her sister died in a car accident. Further on the importance of Léonie's speech, see Coppel (1997: 22-26). 
was, acknowledged in the early-twentieth century by important Indonesian intellectuals. In 1906 Dr Abdul Rivai, enlightened progressive Indonesian, published a series of ten articles dedicated to the kaoem moeda bangsa Tjina, in a magazine with 15,000 subscribers throughout the Archipelago. This was to honour their achievement in the pursuit of kemadjoean (progress). Later, however, this contribution dropped out of the lineage of Indonesian nationalism, and was mentioned only occasionally. ${ }^{47}$ This present essay is another step on the way towards clarifying the role and contribution of Chinese women, who have so far been overlooked. Considering the inspirational impact of the bangsawan prampoewan's enlightening achievements on nonChinese women, it is more than appropriate they be included in the grand narrative of the nation's women's movement history.

\section{REFERENCES}

35 Jarig Jubileum Tiong Hoa Hwee Kwan Malang 1904-1939. 1940. Malang: THHK. Adam, Ahmat. 1985. "The Bintang Hindia and the Pursuit of 'Kemajuan' for Indonesians", Jurnal Antropologi dan Sosiologi 13: 3-14.

Adam, Ahmat. 1995. The vernacular press and the emergence of modern Indonesian consciousness (1855-1913). Ithaca, NY: SEAP Cornell University.

Algemeen vijfjarig verslag van het inlandsch onderwijs in Nederlandsch Indië. 18801907. Batavia: Landsdrukkerij. [Various editions from 1873-1904.]

Anderson, Benedict. 1979. "A time of darkness and a time of light; Transposition in early Indonesian nationalist thought", in: Anthony Reid and David Marr (eds), Perceptions of the past in Southeast Asia, pp. 219-248. Kuala Lumpur: Heinemann.

Bliek, A.J. 1910. "De zendingbond en de Inlandsche pers", in: Overzicht van de dertiende zending-conferentie gehouden te Salatiga van 4 tot 12 September 1909. Weltevreden: Visser.

Campbell, Donald Maclaine. 1915. Java; Past \& present; A description of the most beautiful country in the world, its ancient history, people, antiquities, and products. Vol. II. London: William Heinemann.

Carey, Peter B.R. 1984. "Changing Javanese perceptions of the Chinese communities in Central Java, 1755-1825", Indonesia 37 (April): 1-47.

Chen Mong Hock. 1967. The early Chinese Newspaper of Singapore 1881-1912. Singapore: University Malaya Press.

“Chineezen”. 1917. "Chineezen”, in: J. Paulus (ed.), Encyclopaedie van Nederlandsch-Indië. Deel I. 's-Gravenhage: Nijhoff.

Cohen, Matthew Isaac. 2006. The Komedie Stamboel; Popular theater in colonial Indonesia 1891-1903. Athens, OH: Ohio University Press.

Coppel, Charles. 1997. "Emancipation of the Chinese woman", in: Jean Gelman Taylor (ed.), Women creating Indonesia; The first fifty years, pp. 2251. Melbourne: Monash Asia Institute, Monash University. 
Coté, Joost. 1992. Letters from Kartini, an Indonesian feminist, 1900-1914. Clayton, Victoria: Monash Asian Institute, Monash University. [Translation of Kartini; Brieven aan Mevrouw R.M. Abendanon-Mandri en haar echtgenoot, F.G.P Jaquet (1987), Dordrecht: Foris.]

Coté, Joost. 1995. On feminism and nationalism; Kartini's letters to Stella Zeehandelaar, 1899-1903. Clayton, Victoria: Monash Asia Institute, Monash University.

Douglas, Carstairs. 1873. Chinese-English dictionary of the vernacular or spoken language of Amoy, with the principal variations of the Chang-chew and Chinchew dialects. London: Trübner.

Douwes Dekker, E.F.E. 1909. "The press", in: Arnold Wright and Oliver T. Breakspear (eds), Twentieth century impressions of Netherlands India, pp. 261-267. London: Lloyd.

Edwards, Louise. 2007. “Dressing for power; Scholars' robes, school uniforms and military attire in China", in: Mina Roces and Louise Edwards (eds), The politics of dress in Asia and the Americas, pp. 42-64. Brighton: Sussex Academic Press.

Embree, Bernard L.M. 1973. A dictionary of Southern Min. Hong Kong: Hong Kong Language Institute.

End, Th. van den. 2006. Sumber-sumber Zending tentang sejarah gereja di Jawa Barat 1858-1963. Jakarta: BPK Gunung Mulia. [Seri sumber-sumber sejarah gereja di Indonesia 3.]

Fromberg,P.H.1926. Verspreide geschriften. Leiden: LeidscheUitgeversmaatschappij.

“The Geisha”. 2001. "The Geisha”, in: Kurt Gänzl, The encyclopedia of the musical theatre. Second Edition. New York, NY: Schirmer Books.

Godley, Michael R. 1981. Mandarin capitalists from Nanyang; Overseas Chinese enterprise in the modernization of China 1893-1911. New York, NY: Cambridge University Press.

Govaars-Tjia, Ming Tien Nio. 2005. Dutch colonial education; The Chinese experience in Indonesia, 1900-1942. Translated by Lorre Lynn Trytten. Singapore: Chinese Heritage Centre.

Groeneboer, Kees. 1998. Gateway to the West; The Dutch language in colonial Indonesia, 1600-1950; A history of language policy. Amsterdam: Amsterdam University Press.

Hadler, Jeff. 2008. Muslim and matriarchs; Cultural resilience in Indonesia through jihad and colonialism. Ithaca, NY: Cornell University Press.

Hagen, James M. 1997. "'Read all about it'; The press and the rise of national consciousness in early twentieth-century Dutch East Indies society", Anthropological Quarterly Vol. 70 No. 3 (July): 107-126.

Hall, Bruce Edward. 1998. Tea that burns; A family memoir of Chinatown. New York, NY: The Free Press.

Hashimoto, Yorimitsu. 2005. “Japanese tea party; Representation of Victoria paradise and playground in "The Geisha (1896)", in: John K. Walton (ed.), Histories of tourism; Representation, identity, and conflict, pp. 104-124. Clevedon: Channel View Publications. 
Hirano, Ken'ichiro. 1993. “The westernization of clothes and the state in Meiji Japan", in: Hirano Ken'ichiro (ed.), The state and cultural transformation; Perspectives from East Asia, pp. 121-131. Tokyo: United Nations University Press.

Hutchinson, John. 2001. "Intellectuals and nationalism", in: Athena S. Leoussi (ed.), Encyclopaedia of nationalism, pp. 154-157. New Brunswick: Transaction Publishers.

"Hybridity". 2000. "Hybridity", in: Bill Ashcroft, Gareth Griffiths, and Helen Tiffin, Post-colonial studies; The key concepts, p. 118. London: Routledge.

Jaquet, L.G.P. (ed.). 1989. Kartini; Surat-surat kepada Ny. R.M. Abendanon-Mandri dan suaminya. Translated by Sulastin Sutrisno. Jakarta: Djambatan.

Kartini. 1912. Door duisternis tot licht; Gedachten over en voor het Javaansche volk. 's-Gravenhage: Luctor et Emergo.

Kartini. 1964. Letters of a Javanese princess. Translated by Agnes Louise Symmers and edited by Hildred Geertz. New York, NY: W.W. Norton.

Koloniaal Verslag 1878-1898.

Koo, Madame Wellington and Isabella Taves. 1975. No feast lasts forever. New York: Quadrangle.

Kunio,Yoshihara (ed.). 1989. Oei Tiong Ham; The first business empire in Southeast Asia. Kyoto: CSEAS Kyoto University.

Kwartanada, Didi. 2013. “The Tionghoa Hwee Koan School; A transborder project of modernity in Batavia c. 1900s", in: Sai Siew Min and Chang YauHoon (eds), Chinese Indonesian reassessed; History, religion and belonging, pp. 27-44. London/New York: Routledge.

Kwee Kek Beng. 1936. “Het cultureele leven der Chineezen in NederlandschIndië", Koloniale Studiën 5/6: 78-97.

Kwee Tek Hoay. 1969. The origins of the modern Chinese movement in Indonesia. Translated and edited by Lea E. Williams. Ithaca, NY: SEAP Cornell University.

Kwee Tek Hoay. 2001. "Atsal moelahnja timbul pergerakan Tionghoa yang modern di Indonesia", in: Marcus AS and Pax Benedanto (eds), Kesastraan Melayu Tionghoa dan kebangsaan Indonesia, pp. 393-534. Jakarta: Kepustakaan Populer Gramedia.

Lake, Andrew. 2004. Changes \& chances; A personal history of all saints Jakarta. Jakarta: All Saints Church.

Liem Thian Joe. 1933. Riwajat Semarang. Semarang: Ho Kim Yoe.

Liem Tjwan Ling. 1979. Raja gula Oei Tiong Ham. Surabaya: Liem Tjwan Ling. Lohanda, Mona. 2002. Growing pains; The Chinese and the Dutch in colonial Java, 1890-1942. Jakarta: Cipta Loka Caraka.

Mrázek, Rudolf. 2002. Engineers of happy land; Technology and nationalism in a colony. Princeton: Princeton University Press.

Nio Joe Lan. 1939. "De eigen onderwijsvoorziening der Chineezen", Koloniale Studiën 1: 67-94.

Nio Joe Lan. 1940. Riwajat 40 taon dari Tiong Hoa Hwe Koan-Batavia (1900-1939). Batavia: Tiong Hoa Hwe Koan. 
Nio Joe Lan. 1962. Sastera Indonesia-Tionghoa. Djakarta: Gunung Agung.

Onghokham. 1982. "The Peranakan Officers' families in nineteenth century Java", in: G.J. Schutte (ed.), Papers of the Dutch-Indonesian historical conference held at Lage Vuursche, pp. 278-291. Leiden: Bureau of Indonesian Studies.

Papastergiadis, Nikos. 2000. "Tracing hybridity in theory”, in: Pnina Werbner and Tariq Modood (eds), Debating cultural hybridity; Multi-cultural identities and the politics of anti-racism, pp. 1-17. London: Zed Books.

Pitt Kuan Wah et al. 1988. Wayang; A history of Chinese opera in Singapore. Singapore: National Archives.

Poeze, Harry A. 1986. In het land van de Overheerser. Deel I: Indonesiërs in de Nederland 1600-1950. Dordrecht: Foris.

Poeze, Harry A. 1989. “Early Indonesian emancipation; Abdul Rivai, Van Heutsz and the Bintang Hindia", Bijdragen tot de Taal-, Land-en Volkenkunde 145 (1): pp. 87-106.

Poon, Joanne Mei-chu. 1997. “Miss Queen of Cathay and the Chinese community of Vancouver, 1953-54", in: Steven Tötösy de Zepetnek and Jennifer W. Jay (eds), East Asian cultural and historical perspectives; Histories and society/culture and literatures, pp. 123-134. Edmonton: University of Alberta.

Reid, Anthony. 1985. "From betel-chewing to tobacco-smoking in Indonesia", Journal of Asian Studies 44 (May): 529-547.

Rensselaer Thayer, Mary van. 1943. Hui-Lan Koo [Madame Wellington Koo]; An autobiography. New York, NY: Dial Press.

Ricklefs, M.C. 2007. Polarising Javanese society; Islamic and other visions c. 18301930. Singapore: National University of Singapore Press.

Roces, Mina and Louise Edwards. 2007. “Trans-national flows and the politics of dress in Asia and the Americas", in: Mina Roces and Louise Edwards (eds), The politics of dress in Asia and the Americas, pp. 1-18. Brighton: Sussex Academic Press.

Salmon, Claudine. 1977. “Presse féminine ou féministe?”, Archipel 13: 157-192.

Salmon, Claudine. 1984. "Chinese women writers in Indonesia and their views of female emancipation", Archipel 28: 149-171.

Salmon, Claudine. 1991. "The Han Family of East Java; Entrepreneurship and politics (18th-19th centuries)", Archipel 41: 53-87.

Santoso, Wartini (ed.). 1984. Katalog surat kabar koleksi Perpustakaan Nasional 1810-1984. Revised edition. Jakarta: Perpustakaan Nasional.

Schlegel, G. 1891. "Chinese-Malay and Javanese literature in Java", T'oung Pao II: pp. 148-151.

Shiraishi, Takashi. 1990. An age in motion; Popular radicalism in Java, 1912-1926. Ithaca, NY: Cornell University Press.

Song Ong Siang. 1967. One hundred years' history of the Chinese in Singapore. Singapore: University Malaya Press.

Taylor, Anne Robinson. 1981. Male novelists and their female voices; Literary masquerades. Troy, NY: Whitston.

Tio Tek Hong. 2006. Keadaan Jakarta tempo doeloe; Sebuah kenangan 1882-1959. Jakarta: Masup Jakarta. 
Toer, Pramoedya Ananta. 2003. Sang pemula. Jakarta: Lentera Dipantara.

Winichakul, Thongchai. 2000. “The quest for 'Siwilai'; A geographical discourse of civilizational thinking in the late nineteenth and early twentieth-century Siam", Journal of Asian Studies 59/3 (August): 528-549.

Yung, Judy. 2008. "The social awakening of Chinese American women as reported in Chung Si Yat Po, 1900-1911", in: Vicki L. Ruis and Ellen Carol DuBois (eds), Unequal sisters; An inclusive reader in U.S. women's history, pp. 195-207. New York/London: Routledge.

Zaini-Lajoubert, Monique. 1994. L'Image de la Femme dans les Litteratures Modernes Indonesienne et Malaise. Paris: Association Archipel.

\section{BASED ON PERIODICALS}

B. Tionghoa. 1906. "Soerat kiriman", Kabar Perniagaan 19-12-1906: 1.

“Baba Tjoa Tjeng Yang”. 1903. Bintang Hindia 23: 247.

Borel, Henri. 1907. “Een Chineesch concert; Mej. A. Oeitiongham, Mej. Lim Tshoen, Arthur Lim", Weekblad voor Indië 31-3-1907: 1062-1064.

"Concert mej-Oei Tiong Ham". 1907. Perniagaan 5-3-1907.

"De Chineesche School te Buitenzorg". 1912. Koloniaal Weekblad 7-11-1912.

“De Chineesche School te Jogjakarta”. 1912. Koloniaal Weekblad 14-3-1912: 5.

"De eerste Chineesche vaccinatrice". 1914. Koloniaal Weekblad 11-6-1914: 1.

“Een Chineesche vereeniging". 1913. Indische Gids XXXV part I: 246.

Ezerman, R.A. 1908. "Een Chineesch feest te Soerabaja", Weekblad voor Indië 18-10-1908: 524.

"Hal orang prampoewan bangsa Tionghoa jang makan (mengoenjah) sirie dengen ratjes". 1906. Ik Po 5-6-1906: 2.

“Lezingnja R.M. Soeleiman, redacteur soerat kabar 'Taman Pewarta', hal hendak berdiriken soerat kabar". 1909. Perniagaan 2-11-1909.

"Liauw Tong Seng dan Liauw Koei Seng Kleermaker". 1907. Perniagaan 1611-1907: appendix.

Lie. 1932. "Asal moelanja agama Hoed di kota Makassar", Moestika Dharma (I) 9 (December): 306.

L.S. 1909. “Benkoelen”, Perniagaan 2-11-1909: 1.

"Madame Bassett's recital". 1905. Eastern Daily Mail and Straits Morning Advertiser 7-12-1905: 3.

Oei binti Tiang Seng, Dora. 1901. "Dari hal hoeroef elok jang sebagi gambar", Li Po 27-7-1901.

Oei Kok Nio. 1906. "Haroes diperhatiken bagi Liatwi Hoedjin dan Siotjia", Ik Po 12-6-1906: 2

Oei Sioe Nio, Oei Im Nio, and Oei Tjwan Nio. 1904. "Moefakatan", Li Po 1911-1904.

Rivai, Abdoel. 1906-07. “Bangsa Tjina terbangoen (III-X); Kaoem moeda bangsa Tjina”, Bintang Hindia IV: 12-19.

Siotjia K. Lim. 1909. “Hal Pladjaran”, Perniagaan 28-10-1909: appendix.

Tan Siang Nio and Tan Toei Nio. 1904. "Pengharepan”, Li Po 26-11-1904.

Terate van China. 1905. “Oepatjara tachajoel jang amat tersesat", Ik Po 20-21905. 
The Hon. Secretary [Lim Boon Keng]. 1907. “The Singapore Chinese Girls's school (A historical sketch)", Straits Chinese Magazine XI No. 4 (December): 166.

The Straits Times 10-11-1909.

Tjoa Phik Nio. 1906. "Karangan dari Nona Tjoa Phik Nio Besoeki", Ik Po 196-1906: 2.

"Vrouwenblad". 1912. Koloniaal Tijdschrift I: 100-101.

"Wat de Chinees Vertelt". 1908. Koloniaal Weekblad 3-12-1908: 4.

"Wat de Chinees Vertelt". 1909a. Koloniaal Weekblad 1-4-1909: 5.

"Wat de Chinees Vertelt". 1909b. Koloniaal Weekblad 15-4-1909: 5.

"Wat de Chinees Vertelt". 1909c. Koloniaal Weekblad 9-9-1909: 4-5.

"Wat de Chinees Vertelt". 1909d. Koloniaal Weekblad 2-12-1909: 5

"Wat de Chinees Vertelt". 1914. Koloniaal Weekblad 28-5-1914: 7.

Archival ReCORDS

A letter from a Chinese of Makassar. 1906. MvK [Ministerie van Koloniën], 2.10.36.04 \#418., Vb [Verbaal] 28/11/1906, 9-11-1905. Nationaal Archief (NA), The Hague.

Liem Thian Joe. [N.d.]. “Riwajat Kian Gwan”. [Manuscript.]

"Tiong Hoa Lie Hak Hauw (Chineesche Meisjes School)", a bilingual Romanized Malay-Chinese script poster. Chung Hua Hui Archive no. 182, International Instituut voor Sociale Geschiedenis (IISG), Amsterdam

INTERNET RESOURCE

Confucius. 1893. "Confucian Analects", translated by James Legge. [Retrieved from: http://www.sacred-texts.com/cfu/conf1.htm, accessed on 7-112016].

Personal communication

Paul Tickell, Jakarta 4-3-2004. 